\title{
PERBANDINGAN METODE EXPLICIT INSTRUCTION DAN \\ STUDENT TEAMS ACHIEVEMENT DIVISION TERHADAP PRESTASI BELAJAR MATEMATIKA SISWA DALAM POKOK BAHASAN LINGKARAN DITINJAU DARI MOTIVASI BELAJAR SISWA KELAS VIII SMPN 1 SAWAHAN
}

\author{
Oleh \\ Tri Andari \\ IKIP PGRI Madiun
}

\begin{abstract}
Abstrak
Tujuan penelitian adalah untuk mengetahui: 1) Pembelajaran mana yang lebih baik antara metode $S T A D$ dengan metode Explicit Instruction dalam meningkatkan prestasi belajar siswa, 2) Metode mana yang memberikan prestasi belajar matematika yang lebih baik antara siswa yang mempunyai motivasi belajar tinggi, sedang, dan rendah, 3) Ada tidaknya interaksi antara metode pembelajaran dengan motivasi pada prestasi belajar siswa. Teknik pengumpulan data yang digunakan adalah angket untuk data motivasi siswa dan teknik tes untuk data prestasi belajar matematika siswa. Data yang diperoleh dianalisis dengan uji statistik analisis variansi dua jalan frekuensi sel tak sama. Kesimpulan dari penelitian ini adalah 1) tidak ada perbedaan pengaruh antara Pembelajaran dengan menggunakan metode STAD maupun pembelajaran yang menggunakan metode Explicit Instruction dalam meningkatkan prestasi belajar siswa kelas VIII SMP N 1 Sawahan pada pokok bahasan Lingkaran, 2) tidak ada perbedaan pengaruh antara motivasi tinggi, sedang maupun rendah terhadap prestasi belajar siswa kelas VIII SMP N 1 SAWAHAN pada pokok bahasan Lingkaran, 3) tidak ada interaksi antara pengajaran dengan model STAD dan pengajaran dengan model Explicit Instruction dengan motivasi siswa tinggi, sedang maupun rendah terhadap prestasi belajar siswa kelas VIII SMPN 1 Sawahan pada pokok bahasan Lingkaran.
\end{abstract}

Kata Kunci: Metode Student Teams Achievement Division, Explicit

Instruction, Motivasi siswa, Prestasi belajar matematika.

\section{PENDAHULUAN}

Sekolah merupakan suatu tempat untuk melakukan kegiatan pembelajaran guna memperoleh pendidikan dan ilmu. Dalam proses pembelajaran di sekolah guru merupakan faktor penting yang besar pengaruhnya terhadap prestasi belajar. Tugas guru tidak hanya menyampaikan informasi kepada siswa, tetapi harus menjadi fasilitator yang bertugas memberikan kemudahan belajar kepada seluruh siswa, agar mereka dapat belajar dalam suasana menyenangkan, gembira, penuh semangat, tidak cemas dan berani mengemukakan pendapat secara terbuka. Hal ini erat kaitannya dengan metode pembelajaran yang akan digunakan dalam tiap-tiap pelajaran termasuk pelajaran matematika. Matematika disebut sebagai ratunya ilmu. Jadi matematika merupakan sumber dari ilmu yang lain atau dari pengetahuan lain disekolah. Sebagaimana yang tercantum dalam Kurikulum Matematika Sekolah, tujuan diberikannya pendidikan matematika pada jenjang pendidikan dasar dan menengah adalah agar siswa mampu menghadapi perubahan keadaan di dunia yang selalu berkembang, melalui latihan bertindak atas dasar pemikiran secara logis, rasional, kritis, cermat, jujur dan efektif. Hal ini, jelas merupakan tuntutan sangat tinggi yang tidak mungkin bisa dicapai hanya melalui hafalan, latihan pengerjaan soal yang bersifat rutin, serta proses pembelajaran biasa. Untuk menjawab tuntutan yang demikian tinggi, maka 
perlu dikembangkan materi serta proses pembelajaran yang sesuai. Matematika merupakan salah satu mata pelajaran yang dianggap sulit dari mayoritas siswa, maka dari itu seorang guru khususnya guru matematika harus berupaya membuat para siswa senang dengan pelajaran matematika. Agar siswa dapat menerima, menguasai dan lebih mengembangkan bahan pelajaran itu, maka cara mengajar serta cara belajar harus tepat dan seefisien serta seefektif mungkin.

Metode pembelajaran yang mampu menarik serta mampu membangkitkan motivasi siswa untuk belajar tentunya akan sangat mempengaruhi motivasi dan prestasi belajar matematika siswa. Oleh sebab itu seorang guru harus dapat melakukan usaha yang dapat meningkatkan motivasi dan prestasi belajar matematika siswa. Berdasarkan survei peneliti pada siswa kelas VIII, di Sekolah Menengah Pertama SMPN 1 Sawahan, salah satu masalah dalam pembelajaran matematika adalah tingkat motivasi siswa masih kurang. Hal ini dipengaruhi oleh metode pembelajaran yang digunak an guru kurang bervariasi. Prestasi belajar yang didapatkan oleh siswa kelas VIII SMPN 1 Sawahan tergolong masih rendah. Rendahnya prestasi belajar dapat diketahui dari hasil ulangan harian pokok bahasan sebelumnya yaitu pokok bahasan Geometri dan Pengukuran yang menunjukkan 65\% dari 24 siswa yang mencapai SKBM.

Terkait dengan hal tersebut, peneliti mencoba membandingkan metode pembelajaran Explicit Instruction dengan metode pembelajaran Student Teams Achievement Divisions. Metode pembelajaran Student Teams Achievement Division adalah metode pembelajaran dimana dalam proses pembelajaran siswa ditempatkan dalam team belajar beranggotakan 4-5 orang. Merekalah yang harus aktif mengembangankan pengetahuan mereka, bukan guru. Metode pembelajaran Explicit Instruction adalah metode pembelajaran dimana pembelajaran berpusat pada guru. Pada metode pembelajaran Explicit Instruction guru lebih banyak mengajarkan tentang konsep-konsep, tujuannya adalah mengembangkan belajar siswa tentang pengetahuan prosedural dan pengetahuan deklaratif. Pada saat pembelajran siswa cenderung lebih banyak mendengarkan.

Mempertimbangkan hal-hal tersebut, maka dapat dirumuskan permasalahan sebagai berikut.

1. Apakah pembelajaran dengan menggunakan metode Student Teams Achievement Divisions lebih baik daripada metode Explicit Instruction dalam prestasi belajar siswa?

2. Apakah motivasi tinggi lebih baik dari motivasi sedang dan rendah, apakah motivasi sedang lebih baik dari pada motivasi tinggi pada prestasi belajar siswa?

3. Apakah terdapat interaksi antara metode pembelajaran dengan motivasi pada prestasi belajar siswa?

Tujuan dalam penelitian ini adalah untuk mengetahui pembelajaran yang menggunakan metode Student Teams Achievement Divisions lebih baik daripada pembelajaran dengan metode Explicit Instruction dalam prestasi belajar siswa, untuk mengetahui motivasi tinggi lebih baik dari motivasi sedang, motivasi sedang lebih baik dari motivasi rendah siswa dan untuk mengetahui terdapat interaksi antara metode pembelajaran dengan motivasi siswa kelas VIII SMPN 1 Sawahan pada pokok bahasan Lingkaran. 
Prestasi belajar merupakan suatu masalah yang sangat potensial dalam sejarah kehidupan manusi karena sepanjang tentang kehidupannya manusia selalu mengejar prestasi menurut bidang dan kemapuan masing-masing. Kehadiran prestasi belajar dalam kehidupan manusia pada tingkat dan jenis tertentu dapat memberikan kepuasan tersendiri pada manusia. Lanawati (dalam Reni Akbar, 2004:168) berpendapat bahwa prestasi belajar adalah "hasil penilaian pendidik terhadap proses belajar dan hasil belajar siswa sesuai dengan tujuan instruksional yang menyangkut isi pelajaran dan perilaku yang diharapkan dari siswa." Ada empat faktor prestasi belajar yaitu yang pertama adalah faktor-faktor yang ada pada siswa, misalnya taraf intelegensi, bakat khusus, taraf pengetahuan yang dimiliki, taraf kemampuan berbahasa, taraf organisasi kognitif, motivasi, kepribadian, perasaan, sikap, minat, konsep diri, kondisi fisik dan psikis yang ada pada lingkungan keluarga, yang ada pada lingkungan sekolah, dan yang ada pada lingkungan sosial. Kedua yaitu faktor-faktor yang ada pada lingkungan keluarga, misalnya hubungan antar orang tua, hubungan orang tua dengan anak, jenis pola asuh, keadaan sosial ekonomi. Ketiga yaitu faktor-faktor yang ada pada lingkungan sekolah, misalnya guru, kurikulum, organisasi sekolah, sistem sosial di sekolah, keadaan fisik sekolah dan fasilitas pendidikan, hubungan sekolah dengan orang tua, lokasi sekolah. Keempat yaitu faktorfaktor pada lingkungan sekolah, misalnya keadaan sosial, politik, ekonomi, cuaca dan iklim.

Dalam proses belajar, motivasi sangat diperlukan, sebab seseorang yang tidak mempunyai motivasi dalam belajar, tidak akan mungkin melakukan aktivitas belajar. Hal ini merupakan pertanda bahwa sesuatu yang akan di kerjakan itu tidak menyentuh kebutuhannya. Segala sesuatu yang menarik minat orang lain belum tentu menarik orang tertentu selama sesuatu itu tidak bersentuhan dengan kebutuhannya. Syaiful Bahri Djamarah (2002:115) berpendapat bahwa "dalam membicarakan soal macam-macam motivasi hanya akan dipandang dari dua sudut pandang, yakni motivasi yang berasal dari dalam diri pribadi seseorang disebut motivasi intrinsik dan motivasi yng berasal dari luar diri seseorang yang disebut motivasi ekstrinsik." Faktorfaktor yang mempengaruhi motivasi belajar antara lain kematangan, usaha yang bertujuan, pengetahuan mengenai hasil dalam motivasi, partisipasi dan penghargaan dengan hukuman.

Metode pembelajaran perlu dipahami guru agar dapat melaksanakan pembelajaran secara efekti dalam meningkatkan hasil pembelajaran. Dalam penerapannya, metode pembelajaran harus dilakukan sesuai dengan kebutuhan siswa karena masing-masing metode pembelajaran memiliki tujuan, prinsip, dan tekanan utama yang berbeda-beda. M. Sobri Sutikno (dalam Hipni Rohman, 2011) menyatakan bahwa metode pembelajaran adalah "cara-cara menyajikan materi pelajaran yang dilakukan oleh pendidik agar terjadi proses pembelajaran pada diri siswa dalam upaya untuk mencapai tujuan”.

Metode yang digunakan dalam penelitian ini adalah metode Explicit Instruction dan Student Team Achievement Divisions (STAD). Menurut Slavin (terjemahan isjoni, 2009:74) metode Student Team Achievement Divisions (STAD) ini merupakan salah satu tipe kooperatif yang menekankan pada adanya aktivitas dan interaksi dantara siswa untuk saling memotivasi dan saling 
membantu dalam menguasai materi pelajaran guna mencapai prestasi yang maksimal. Langkah-langkah pembelajaran Student Team Achievement Divisions (STAD) adalah (1) penyampaian tujuan yang ingin dicapai dan memotivasi siswa untuk belajar, (2) pembagian kelompok yaitu siswa dibagi menjadi beberapa kelompok secara heterogen setiap kelompok terdiri 4-5 siswa, (3) guru menyampaikan materi pelajaran yang akan diajarkan, (4) guru menyiapkan lembaran kerja sebagai pedoman bagi kerja kelompok dan selama tim bekerja guru melakukan pengamatan, (5) guru memberikan evaluasi hasil belajar melalui pemberian kuis tentang meteri yang dipelajari selama kuis berlangsung siswa dilarang bekerja sama dengan siswa lain, penghargaan prestasi tim.

Metode Pembelajaran Explicit Instruction atau Pengajaran Langsung khusus dirancang untuk mengembangkan belajar siswa tentang pengetahuan prosedural dan pengetahuan deklaratif yang dapat diajarkan dengan pola selangkah demi selangkah. Langkah-langkah pembelajaran Explict Instructions adalah (1) menyampaikan tujuan dan mempersiapkan siswa, mendemonstrasikan pengetahuan dan ketrampilan, (3) membimbing pelatihan, (4) mengecek pemahaman dan memberikan umpan balik, (5) memberikan kesempatan untuk latihan lanjutan.

\section{METODE}

Penelitian ini dilaksanakan di SMPN 1 Sawahan. Waktu penelitian dilakukan pada bulan Maret sampai April 2014. Populasi dalam penelitian ini adalah seluruh siswa kelas VIII SMPN 1 Sawahan. Penentuan sampel dalam penelitian ini dilakukan dengan cara cluster random sampling. Sampel yang diambil oleh peneliti dari populasi adalah sebanyak 2 kelas, yaitu kelas VIIIB sebagai kelas kontrol dan kelas VIIID sebagai kelas eksperimen, dengan melibatkan 48 orang siswa sebagai sampel. Populasi dan Sampel Penelitian adalah siswa kelas VIII SMP 1 Sawahan, yang berjumlah 142 siswa. Data penelitian diperoleh dengan teknik angket dan tes. Bentuk angket berupa angket langsung tertutup dengan jumlah angket sebanyak 25 butir pertanyaan. Benuk tes adalah pilihan ganda dengan jumlah soal 20 butir. Analisis data menggunakan teknik statistik, yang digunakan adalah analisis variansi dua jalan dengan sel tak sama.

\section{HASIL PENELITIAN}

Berdasarkan hasil uji keseimbangan pada kelompok kontrol dan eksperimen, hasil analisis data uji normalitas menunjukkan bahwa $H_{0}$ diterima. Ini berarti, sampel random untuk kelompok kontrol dan eksperimen berasal dari distribusi normal. Hasil analisis data uji homogenitas pada kelompok kontrol dan eksperimen menunjukkan bahwa $H_{0}$ diterima. Ini berarti, data sampel random kelompok kontrol dan eksperimen homogen. Hasil analisis data uji-t menunjukkan bahwa $H_{0}$ diterima. Ini berarti kelompok kontrol dan eksperimen mempunyai kemampuan yang sama.

Berdasarkan hasil validitas dan reliabilitas tes prestasi belajar dan angket motivasi terhadap 24 siswa. Hasil validitas tes prestasi menunjukkan bahwa dari 20 butir soal yang diujikan yang memenuhi kriteria adalah 15 butir soal. Dalam penelitian uji reliabilitas tes pretasi belajar menggunakan rumus Flanagan. Hasil uji coba soal tes matematika menunjukkan bahwa soal tes matematika reliabel dan dapat digunakan untuk mengambil data prestasi belajar siswa. Hasil validitas 
angket motivasi menunjukkan bahwa dari 25 butir angket yang diujikan yang memenuhi kriteria adalah 21 butir angket. Dalam penelitian uji reliabilitas angket motivasi menggunakan rumus Alpha. Hasil uji coba angket motivasi menunjukkan bahwa angket motivasi reliabel dan dapat digunakan untuk mengambil data motivasi siswa.

Berdasarkan hasil uji hipotesis untuk kelompok kontol dan eksperimen. Hasil uji normalitas untuk kelompok kontrol dan eksperimen menunjukkan bahwa $H_{0}$ diterima. Ini berarti, sampel untuk kelompok kontrol dan eksperimen berasal dari populasi yang berdistribusi normal. Hasil uji homogenitas untuk kelompok kontrol dan eksperimen menunjukkan bahwa $H_{0}$ diterima. Ini berarti, sampel untuk kelopok kontrol dan eksperimen berasal dari populasi yang homogen. Berdasarkan hasil uji hipotesis untuk kelompok motivasi tinggi, sedang dan rendah. Hasil uji normalitas untuk kelompok motivasi tinggi, sedang dan rendah menunjukkan bahwa $H_{0}$ diterima. Ini berarti, sampel untuk kelompok motivasi tinggi, sedang dan rendah berasal dari populasi yang berdistribusi normal. Hasil uji homogenitas untuk kelompok motivasi tinggi, sedang dan rendah menunjukkan bahwa $H_{0}$ diterima. Ini berarti, sampel untuk kelompok motivasi tinggi, sedang dan rendah berasal dari populasi yang homogen.

Berdasarkan hasil analisis uji hipotesis menunjukkan bahwa $H_{O A}$ diterima. Ini berarti, tidak ada perbedaan pengaruh antara Pembelajaran dengan menggunakan metode Student Teams Achievement Division maupun pembelajaran yang menggunakan metode Explicit Instruction dalam meningkatkan prestasi belajar siswa. Ini menunjukkan bahwa metode Student Teams Achievement Division maupun metode Explicit Instruction memberikan masukan yang sama terhadap prestasi belajar matematika siswa. Jadi uji pasca anava tidak perlu dilakukan.

Hasil analisis uji hipotesis menunjukkan bahwa $H_{O B}$ diterima. Ini berarti, tidak ada perbedaan pengaruh antara motivasi tinggi, sedang maupun rendah terhadap prestasi belajar siswa. Jadi uji pasca anava tidak perlu dilakukan.

Hasil analisa uji hipotesis menunjukkan bahwa $H_{O A B}$ diterima. Ini berarti, tidak ada interaksi antara pengajaran dengan model Student Teams Achievement Division dan pengajaran dengan model Explicit Instruction dengan motivasi siswa tinggi, sedang maupun rendah terhadap prestasi belajar siswa. Hal ini disebabkan karena antara penggunaan metode pembelajaran dan motivasi siswa mempunyai pengaruh sendirisendiri terhadap prestasi belajar matematika. Jadi uji pasca anava tidak diperlukan.

\section{SIMPULAN DAN SARAN Simpulan}

Berdasarkan hasil penelitian dapat disimpulkan bahwa tidak ada perbedaan pengaruh antara Pembelajaran dengan menggunakan metode Student Teams Achievement Division maupun pembelajaran yang menggunakan metode Explicit Instruction dalam meningkatkan prestasi belajar siswa, tidak ada perbedaan pengaruh antara motivasi tinggi, sedang maupun rendah terhadap prestasi belajar siswa dan tidak ada interaksi antara pengajaran dengan metode Student Teams Achievement Division dan pengajaran dengan metode Explicit Instruction dengan motivasi siswa tinggi, sedang maupun rendah terhadap prestasi belajar siswa.

\section{Saran}


Berdasarkan hasil penelitian ini, maka dapat diajukan saran kepada guru mata pelajaran matematika. Dalam usaha meningkatkan motivasi belajar siswa untuk meningkatkan prestasi belajar, hendaknya dalam pembelajaran menggunakan metodemetode pembelajaran yang berbeda sesuai dengan materi yang dajarkan, misalnya model pembelajaran Student Teams Achievement Division.

\section{RUJUKAN}

Reni Akbar-Hawadi. 2004. Program Percepatan Belajar dan Anak Berbakat Intelektual. Jakarta: PT Grasindo

Budiyono. 2004. Statistik Untuk Penelitian. Surakarta: Sebelas Maret University Press

Hamzah B.Uno. 2009. Mengelola Kecerdasan dalam Pembelajaran Sebuah Konsep Pembelajaran Berbasis Kecerdasan. Jakarta: PT Bumi Aksara.

Syaiful Bahri Djamarah. 2002. Psikologi Belajar. Jakarta: PT Rineka Cipta Reni Akbar - Hawadi, dkk. 2006. Kreativitas: Panduan Bagi Penyelenggaraan Program Peercepatan Belajar . Jakarta: PT Gramedia Widiasarana Indonesia

Sugiyono. 2006. Metode Penelitian Pendidikan Pendekatan Kuantitatif, Kualitatif, dan $R \& D$. Bandung: CV Alfabeta

Suharsimi Arikunto. 2010. Dasar-dasar Evaluasi Pendidikan. Jakarta: Bumi Aksara

Isjoni. 2008. Model-Model Pembelajaran Mutakhir. Yogyakarta: Pustaka Pelajar 